\title{
The Effects of Learning Media and Self-Regulated Learning on the Students Achievement in Accounting Computer Courses (The Case Study at Class XII SMK DEK Business School Padang)
}

\author{
Diah Ramadani' ${ }^{1}$ Susi Evanita ${ }^{2}$, Marwan $^{3^{*}}$ \\ ${ }^{1}$ DEK Business School Padang, Padang, Indonesia, $\triangle$ diah@dek.sch.id \\ ${ }^{2}$ Universitas Negeri Padang, Padang, Indonesia, $\bowtie$ susievanita@gmail.com \\ ${ }^{3}$ Universitas Negeri Padang, Padang, Indonesia, $₫$ marwanusman@gmail.com \\ *Corresponding Author
}

\begin{abstract}
In last decade, the needs of accounting computer skills were very needed in the workforce. However, some of Vocational High School students were not still skilled in operating the accounting computer program. To resolve that case, so the teacher should use the right learning media in the learning process. One of the right learning media was the accounting computer module. This accounting computer module was purposed the students could learn independently. At this time, the students' self-regulated learning was very low. The students were very dependent on the teacher. This research purposed to know how the effects of using the accounting computer module and self-regulated learning toward the students' learning result and then, to know the interaction in using the accounting computer module with self-regulated learning. The method of this research was quasi experiment. At the end of this research showed that there were the significant effects from using accounting computer module toward the students' learning result, the significant effects from selfregulated learning of accounting computer toward the students' learning result, and then there was not the interaction between the uses of accounting computer module with selfregulated learning.
\end{abstract}

Keywords: learning media, self-regulated learning

\section{Introduction}

In the era of globalization like now, the technology is flourishing. Everything activities that are related with the technology such as the use of computer in working. The breakthrough always appears every year to facilitate humans in working that is included the breakthrough about the accounting software has been used by many offices right now. The uses of this accounting software are very helpful and ease an accountant's job compared with manual way. It wastes the time and the result is less efficient. Based on the thing, so SMK the course of Business and Management on Accounting Study Program holds one of the subjects that have an important role in improving the quality of graduates is accounting computer. The aim of the Accounting Computer subject is the students are able to operate the accounting computer application precisely and correctly.

In the Regulation of National Education Minister Number 22 Year 2006 about the standard of contents, the Accounting Computer Subject in Vocational High School (SMK) Business and Management at class XII odd semester is found a competency standard that is to operate the accounting computer application. The students are demanded to be able to do the operation of the accounting computer application precisely. To reach that thing, the students have to take some stages that are started from preparing the preliminary data of the company, creating the account chart, making the ledger, entering the first balance, entering the data of the financial transaction, making the report, and making the backup file. Generally, the students often get difficulty to understand the stage to be input the financial transaction data, because the material for this stage is more numerous and complex. The data input material of the financial transaction has to do precisely and correctly from the initial steps because if it happens a mistake so that it will have the impact toward the next transactions. 
Based on the writer's observation and the discussion result with the friend in the same profession, it found that during the process of accounting computer learning (MYOB), the teacher still used the infocus media with the speech method and the tutorial directly. The teacher explained the material and the students listened, observed and then practiced it directly. In this thing, the learning process was more centered on the teacher (teacher center). In the process of the accounting computer learning (MYOB), the students were often difficult in following the teacher's instruction. The catch power of each students were different, so that in processing the accounting computer learning (MYOB), the teacher was troubled in guiding each of the students with the result, the learning time became less effective. The weakness from the using of infocus media with this tutorial way directly was the desire of the students' self regulated learning became lower, because the students just hoped the material explanation from the teacher. Moreover, to be difficult held the classical learning because the teacher must serve the students in many amounts and the students could not learn with the exact velocity by the own ability because it was influenced by the velocity of the other students.

The education quality can materialize if the learning process is holding effectively; it means the learning process can run swiftly, aimed, and appropriate with the learning goal. Many factors that influence the learning process, not only from the students 'selves but also from the other obstacle factors such as the educators/the teachers, the facilities, the environments, then the use of the learning media. The students are active and creative those are supported by the facilities, then the teacher who masters the material and the delivery strategy effectively, it will more increase the learning quality. However, to achieve the maximum result, many factors that still becomes the obstacles.

The education media as one of the tools increase the education quality which is very important in the learning process. The using of the education media can help the students' learning process in the teaching learning process that it can enhance the students' learning result which is achieved. Module is one of the learning media in which are founded materials, methods, and evaluations that are made systematically and structurally as an effort to reach the competence goal which is expected. The benefits of this module learning media are expected that it will motivate the students to learn independently, creatively, effectively, and efficiently. Besides that by this module learning media, it is expected can decrease the students' bored because during this time, the leaning process that is done by some teachers is a face to face method (talkative) which it causes the students become saturation and bored that effects the students' motivation go down.

Therefore, according to the writer, need to give the learning material such as Accounting Computer Module (MYOB) that is appropriate with the necessary and the target characteristic are expected. According to Hamalik (2007:171), the teaching effectively is the teaching that supplies the learning opportunity individually or does the activity individually. In the constructivist learning concept, the students build their own knowledge, it means that the teacher has a role how to create the students to learn actively, do not accept the knowledge from the teacher. Through the teaching material like a module, it will create the learning effectively and constructivist so that the learning result is better eventually. Based on the research result from Hariyanto (2006) shows that there are the significant effects of Accounting Computer Module Learning On the students accivement in Accounting Computer SMK Nusatama Padang Tahun 2006 (Hariyanto:2006).

Slameto (2003:54) states that the learning success is not only influenced from the external factors like the explanation above, but also there are two factors, these are internal and external factor. The internal factor is the factor that is generated from within the individual self particularly an interest and a motivation which will push the students to be independent in learning, while the external factor is the factor that is appeared from the condition growing in outside of the student private life such as the family environment, the school environment and the society.

According to Hasan Basri (2011:54), one of the factors that is also influential toward the learning result is the students' self-regulated learning. Self-regulated is one of the individuality aspects which are very important for the individual. The individual that has high self-regulated can confront all of the problems relatively because the independent individual is not depended in others, always try to confront and solve the problems. Haris Mujiman (2007:1) claims that the independent learning is the 
active learning activities which are pushed by the motives to master a competence, and built with the knowledge provision or the competence which has been had.

Self-regulated learning is the learning activity conditions that is independent no depended on others, it has a desire and also a responsible for own in solving their learning problems. Self-regulated learning will be materialized if the students are active in controlling everything is done individually, evaluate and then meditate something more in the learning that is doing and the students also want to be active in the learning process. As a conclusion that Self-regulated learning is the attitude points to the independent learning awareness and all of the decisions, the judgments which are related to the learning activity cultivated individually so that responsible perfectly in the learning process.

Based on the writer's interview result with the teacher of Accounting Computer (MYOB), the students' self-regulated learning was lower. This thing was proved from interviewing with the students at class XII SMK DEK Business School Padang, which explained no one from the students who bought the learning book of accounting computer (MYOB). The students only relied on the material that was given by the teacher in the school. Thus, the teacher should be able to give the positive stimulus like the learning media that can grow the students' self-regulated learning to be actively involved in learning. It can be done by the teacher with using the learning media such as Accounting Computer Module which is expected can affect self-regulated learning of the students' Accounting Computer and in the end, it will influence the learning result of the students' Accounting Computer. The purpose of this research is to know how the effects of using the accounting computer module media (MYOB) on the students accivement in Accounting Computer, how the effect of the self-regulated learning of Accounting Computer on the students accivement in Accounting Computer, and how the interaction between the learning media and the self-regulated learning in affecting the learning result of the accounting computer.

\section{Methods}

This research was experiment. The method of this research was Anova two varians. This research was held at class XII SMK DEK Business School Padang. This research was held on the odd semester in year 2017/2018 on October until November 2017. The population in this research was the students at class XII in the competence of accounting skill SMK DEK Business School Padang, consist of 2 classes. The sample of this research was total sampling which all populations were become as sample (Sugiyono, 2014:124), was the students at class XII 1 was 19 students and class XII 2 was 18 students. Furthermore, in a random the students at class XII 1 was 19 students were set as the experiment class and the students at class XII 2 was 18 students as the control class.

This research used the factorial design $2 \times 2$ with the treatment like 2 (two) learning models were the use of the module and the conventional learning. The students' self-regulated learning was distinguished to be high self-regulated learning and low self-regulated learning. This research plan could be seen on the table below:

Table 1 The Research Plan

\begin{tabular}{lcc}
\hline \multicolumn{1}{c}{$\begin{array}{c}\text { Learning Media } \\
\text { (A) }\end{array}$} & \multicolumn{2}{c}{ self-regulated learning (B) } \\
\cline { 2 - 3 } & High (B1) & Low (B2) \\
\hline Accounting Computer Module Media (A1) & A1B1 & A1B2 \\
\hline Conventional Media (A2) & A2B1 & A2B2 \\
\hline
\end{tabular}

Explanation :

A1B1 : The students' learning result who had high self-regulated learning that were taught by using Accounting Computer Module

A1B2 : The students' learning result who hadlow self-regulated learning that were taught by using Accounting Computer Module

A2B1 : The students' learning result who had high self-regulated learning that were taught by using Conventional Media 

by using Conventional Media

In this research, the instrument that was used to see the effect of using Accounting Computer Module (MYOB) toward the learning result was the learning result test. The test question items were arranged based on the indicators from each base competence. The learning result tests consisted of the knowledge test and skill test. Whereas, to see the self-regulated learning was used the questionnaire instrument of self-regulated learning of Accounting Computer. The trial of the learning result instrument was done by the validity test, the reliability test, the distinguish power test and the difficulty level test by using the anatest program version 4.0.9. Meanwhile, the instrument trial of the self-regulated learning was done by validity test and the reliability used software IBM SPSS Statistics Version 15.0. The data analysis that was used was two ways analysis of variance which was used to examine the hypotheses. The techniques that were used in doing the analysis rule test was the normality test and homogeneity test.

\section{Results and Discussion}

Based on the data analysis that is done, obtained the result as follows:

Table 2 The Account Results of Anova Two Varians

\begin{tabular}{lllll}
\hline Source & df & $\begin{array}{l}\text { Mean } \\
\text { Square }\end{array}$ & F & Sig. \\
\hline Learning Media & 1 & 1077,441 & 5,868 & 0,021 \\
\hline self-regulated learning & 1 & 2087,7 & 11,371 & 0,002 \\
\hline $\begin{array}{l}\text { Learning Media * } \\
\text { self-regulated learning }\end{array}$ & 1 & 282,908 & 1,541 & 0,223 \\
\hline
\end{tabular}

Based on the table above, it could be seen the account result of Anova two varians. The first hypothesis, the value was obtained Sig. 0,021. It mean that the value Sig.hit $<$ from the value $\alpha(0,05)$, so that $\mathrm{H} 0$ rejected and $\mathrm{H} 1$ accepted. It could be concluded that the students' learning result that was taught by using Accounting Computer Module significantly higher than the students' learning result that was taught by the conventional learning at class XII SMK DEK Padang. The second hypothesis, the value was obtained Sig. 0,002. It mean that the value Sig.hitung < from the value $\alpha(0,05)$, so that $\mathrm{H} 0$ rejected and $\mathrm{H} 1$ accepted. The conclusion from the second hypothesis was the students who had high self-regulated learning about the subject of Accounting Computer significantly it had higher learning result than the students' learning result that had low self-regulated learning about the subject of Accounting Computer at class XII SMK DEK Padang. Meanwhile, the last hypothesis, the value was obtained Sig. 0,223. It mean that the value Sig.hit $>$ from the value $\alpha(0,05)$, so that $\mathrm{H} 0$ accepted dan $\mathrm{H} 1$ rejected. It could be sum up that; there was no interaction between the using of the learning media with the students' self-regulated learning about the subject of Accounting Computer toward the learning result of Accounting Computer at class XII SMK DEK Padang.

The Differences Between the use of Accounting Computer Media Module (MYOB) and the Learning Conventional toward the Learning Result of Accounting Computer

In the learning process for the students that were taught to use Accounting Computer Media Module more emphasized to the practice train approach and the active participation from the students. The students could do the activities individually or group and more organized their learning time it selves. Every material, there were in the module at the same time it had the functions as a guidance to do a practice. This thing was appropriate with Hamalik's declaration (2007:171), Hamalik states that the effective teaching is the teaching which supplies the individual learning opportunity or does the individual activity. In the constructivist learning concept, the students build their own knowledge; it mean that the teacher had a role how to create the students to learn actively, 
did not to accept the knowledge from the teacher. Through the learning material like the module, it would make the learning effectively and constructively so that later the learning result was also better. As long as the students did the practice training of the accounting computer so it would be higher skill level and the students' learning result. The students who learned by using the accounting computer module, it was proved more skilled than the students who learned without using the accounting computer module. This could be seen from the table below:

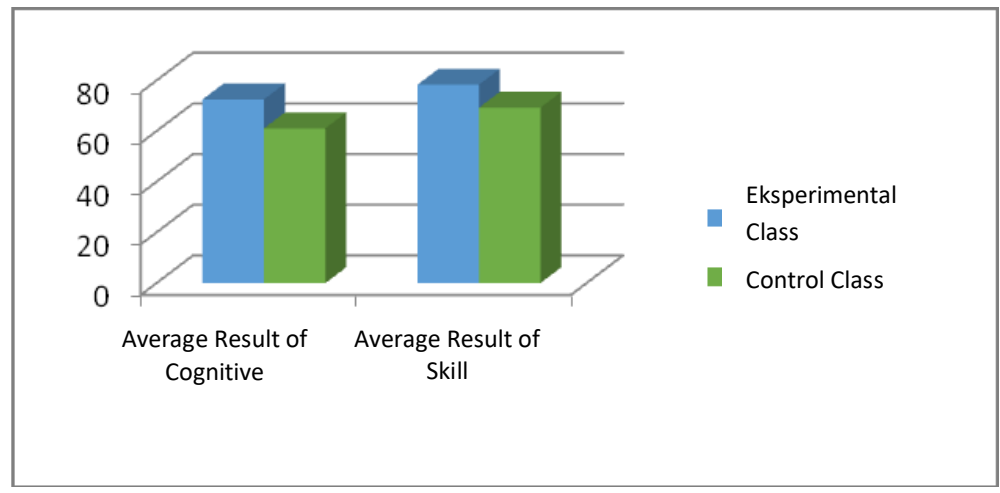

\section{Figure 1 The Comparison of the Value Average of Accounting Computer at the Experiment Class and the Control Class}

Based on the table above, it could be seen that the learning result average of the students' accounting computer at the experiment class higher than the control class, included from the knowledge test and the skill test. This mean that the students who learned by using the accounting computer module more superior than the students who learned without using the accounting computer module. This statement was also proved through the figure 2, it was the attainment level comparison of KKM value (kriteria ketuntasan minimal) of the accounting computer. The KKM value of the accounting computer in SMK DEK Business School Padang is 80.

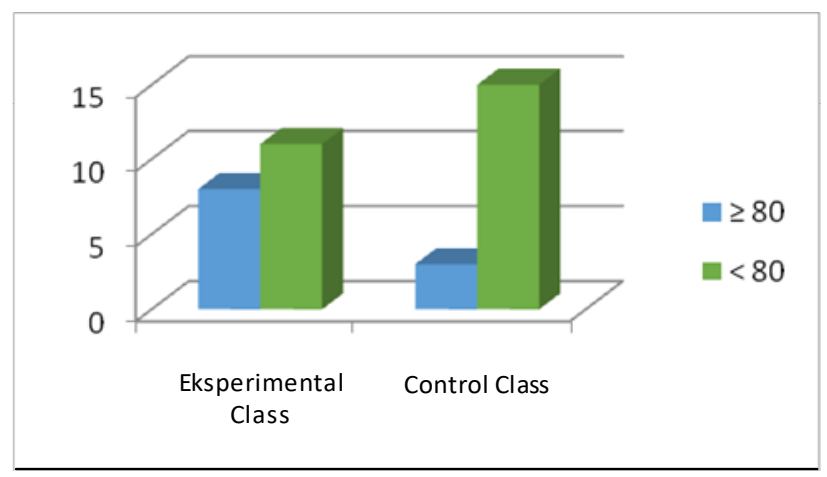

Figure 2 The Comparison of KKM Value Attainment of the Accounting Computer at the Experiment Class and Control Class.

The Differences Between the Students Who Have High Self-Regulated Learning and Low SelfRegulated Learning in the Subject of Accounting Computer On The Students Accivement In Accounting Computer At Class XII SMK DEK Business School Padang.

Related to the test result from the second hypothesis, that the students' learning result who had high self-regulated learning significantly higher than the students' learning result who had low selfregulated learning at class XII SMK DEK Padang. From the test result showed that the students who 
had high self-regulated learning about the subject of Accounting Computer would get the learning result better. This thing could be seen on the figure 3 as follows:

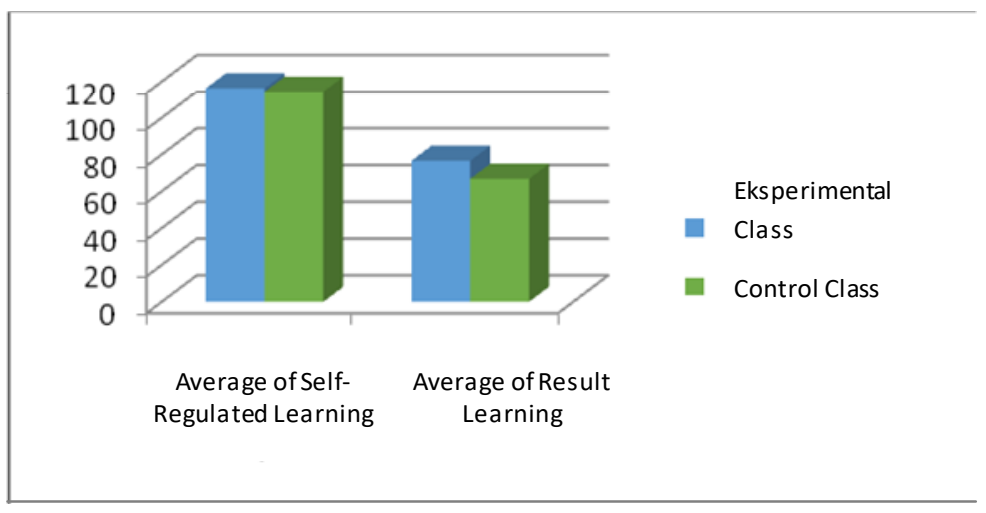

Figure 3 The Comparison Of Self-Regulated Learning Average With the Learning result Average Of the Students' Accounting Computer at the Experiment Class and Control Class

The students who had high self-regulated learning were the students who could do the learning tasks without hoping the others' help. In the action, the students' selves tried to take the various ways to have the mastery toward the concept or the learning material which were learned. Through the various ways, the students' skill would increase so that the students could finish the learning task well and also reached the higher learning result. The research result that was done by Aini and Taman (2012), explain that the students who have high self-regulated learning have the higher learning result than the students who have low self-regulated learning about the Accounting subject. Same with the Aini and Taman s' research result, the writer's research result showed that the students' learning result about the subject of Accounting Computer along with high self-regulated learning about the subject of Accounting Computer significantly higher than the students' learning result who had low self-regulated learning about the subject of Accounting Computer.

The Interaction Between the Uses of Accounting Computer Module with The Students' SelfRegulated Learning about The Subject of Accounting Computer toward The learning Result of Accounting Computer.

An interaction could happen if one of the influential to the other factors in affecting something. Based on the test result from the last hypothesis, showed that there was no the interaction between the uses of the learning media with the students' self-regulated learning about the subject of Accounting Computer. From this finding, so two things that affected the learning result of Accounting Computer were the learning media and the students' self-regulated learning about the subject of Accounting Computer apparently they did not interact each other. So, the effect toward the learning result was contributed by the learning media and self-regulated learning about the subject of Accounting Computer separately. The learning media had the own position in affecting the learning result of Accounting Computer and also with self-regulated learning about the subject of Accounting Computer had the own position in affecting the learning result of Accounting Computer. It could be seen on Figure 4 bellow: 


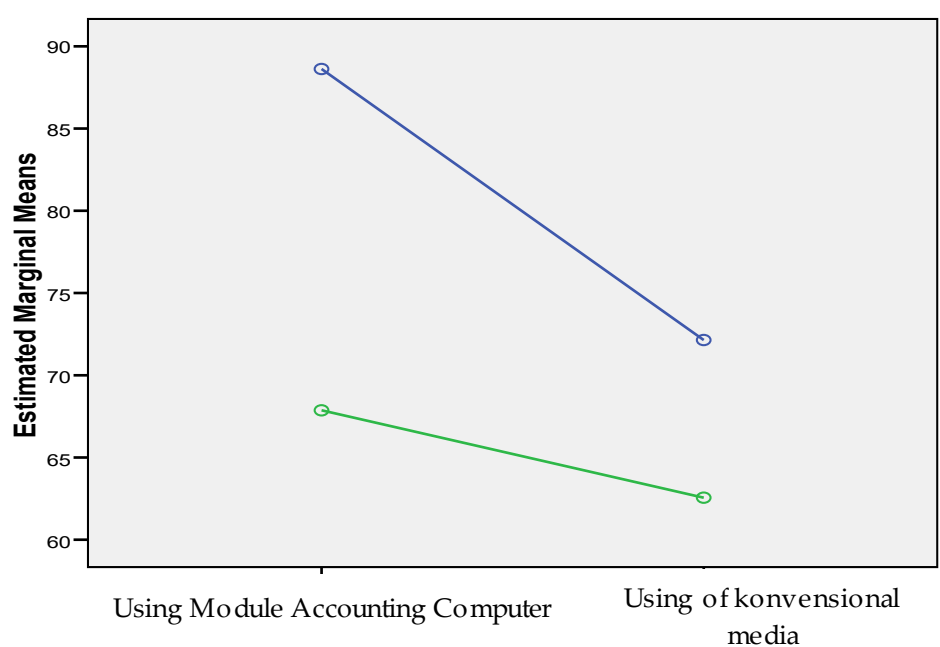

Self-Regulated Learning

- $\begin{aligned} & \text { High } \\ & \text { Low }\end{aligned}$

Figure 4 Estimated Marginal Means of Result Learning

The learning result could be affected by many factors included from the students' selves or the students' environment. Slameto (2003:54) claims that the leaning success is affected by two factors; these are the internal factor and the external factor. The internal factor is the factor is appeared from the individual self particularly the interest and the motivation which will push the students to act independently in learning meanwhile the external factor is the factor is come from the condition that develop in outside of the students' life such as the family environment, the school environment, and the society.

In this research, there was no the interaction between the uses of the learning media with selfregulated learning about the subject of Accounting Computer, it might be caused by the factor which was still many students who had low self-regulated learning of Accounting Computer, so that the students were less excited in learning and less motivated to increase their sill in understanding the learning material.

One of the other cause factors was the exhaustion factor. On November 2017, where this research was held at the same time the students SMK DEK were also busy with the examination implementation of 1 UBK simulation (ujian berbasis computer) that was held suddenly on the second week on November and continued on the third week with Tryout UKK (Ujian Kompetensi Keahlian). Based on the exhaustion factor, it might be the students could not be concentration with the subject of Accounting Computer. By many factors that affected the learning result, so in this research estimated it caused there was no the interaction between the uses of the learning media and the students' selfregulated learning about the subject of Accounting Computer on the students accivement in Accounting Computer at class XII SMK DEK Padang.

\section{Conclusions}

Based on the data analysis, the hypothesis test result and the research discussion result that was gotten, it can be taken some conclusion as follows, The learning result of the students' Accounting Computer who was taught by using Accounting Computer Module Media was higher than the students that were taught by using the conventional media, The learning result of the students' Accounting Computer who has high self-regulated learning about the subject of Accounting Computer was higher than the students who have low self-regulated learning about the subject of Accounting Computer, The uses of the learning media did not interact with the students' selfregulated learning about the subject of Accounting Computer in affecting the leaning result of the students' Accounting Computer at class XII SMK DEK Business School Padang. 
Related to the research result above, so to increase the student accivement in Accounting Computer, the researcher informs several suggestions For the students, are hoped to habituate themselves in learning independently by increasing the reading interest in order that the learning with the module can run effectively. For the teachers, are expected to use Accounting Computer Module Media in the learning process of Accounting Computer, so that the learning is more effective and the teachers do not be difficulties more in guiding or serving every student. For the next researchers, are hoped to do the research of the learning media development which more follow the technology development like the uses of the interactive module of Accounting Computer subject. The interactive module can also be opened through the Smartphone of every student. The interactive learning media like that is more effective than the print module and also more interest the students' attention, so that it is hoped can more increase the students' learning result of Accounting Computer subject.

\section{References}

Ali, Mohammad dan Mohammad Asrori. (2005). Psikologi Remaja. Perkembangan Peserta Didik. PT Bumi Aksara.

Anwar, Ilham. (2010). Pengembangan Bahan Ajar. Bahan Kuliah Online. Direktori UPI. Praktikum akuntansiung.

Arikunto, Suharsimi. (2009). Dasar-dasar Evaluasi Pendidikan. Jakarta : Bumi Aksara

(2006). Prosedur Penelitian Suatu Pendekatan Praktek. Edisi Revisi V. Jakarta : Rhineka Cipta.

Arsyad, A. (2007). Media Pembelajaran. Jakarta : Raja Grafindo Persada.

Asyhar, Rayanda. (2012). Kreatif Mengembangkan Media Pembelajaran. Jakarta: Gaung Persada (GP) Press Jakarta.

Dimyati dan Mudjiono. (2009). Belajar dan Pembelajaran. Jakarta : Rhineka Cipta.

Dit PSMK. (2008). Dasar Kompetensi dan Kompetensi Kejuruan Program Studi Keahlian Akuntansi. Jakarta : Dit PSMK Dirjen MPDM Depdiknas.

Fasikhah, Siti Suminarti dan Fatimah, Siti Fatimah. (2013). Self-regulated Learning (SRL) dalam Meningkatkan Prestasi Akademik pada Mahasiswa. Fakultas Psikologi. Universitas Muhammadiyah Malang.

Fees, Reeve dan Warren. (2008). Pengantar Akuntansi. Jakarta : Salemba Empat

Hamalik, Oemar. (2007). Proses Belajar Mengajar. Jakarta : Bumi Aksara

Aksara.

(2008). Perencanaan Pengajaran Berdasarkan Pendekatan Sistem. Jakarta: PT Bumi

Hariyanto. (2006). Pengaruh Pembelajaran Modul Komputer Akuntansi Terhadap Hasil Belajar Komputer akuntansi Siswa SMK Nusatama Padang. Universitas Negeri Padang : Pasca Sarjana.

Irianto, Agus. (2010). Statistik Konsep Dasar dan Aplikasinya. Jakarta : Kencana.

Miarso, Yusuf Hadi. (2004). Teknologi Komunikasi Pendidikan. Jakarta: Rajawali.

Mudjiman, Haris. (2011). Manajemen Pelatihan Berbasis Belajar Mandiri. Yogyakarta: Pustaka Pelajar.

Prastowo, Andi. (2012). Panduan Kreatif Membuat Bahan Ajar Inovatif. Yogyakarta: Diva Press.

Purwanto. (2011). Evaluasi Hasil Belajar. Yogyakarta : Pustaka Belajar

Purwanti Endang dan Nur Widodo. (2005). Perkembangan Peserta Didik. Malang: Universitas Muhammadiyah Malang.

Rahmiyati, Anis. (2017). Pengaruh Self Regulated Learning Terhadap Prestasi Belajar Siswa Kelas X pada Mata Pelajaran Ekonomi. Universitas Tanjungpura Pontianak.

Riduwan. (2006). Cara Menggunakan dan Memakai Analisis Jalur. Bandung: Alfabeta.

Sadiman, Arief S. (2003). Media Pendidikan. Jakarta: Raja Grafindo Persada.

Slameto. (2010). Belajar dan Faktor-Faktor Yang Mempengaruhinya. Jakarta : Rineka Cipta

Sudjana, Nana. (2011). Penilaian Hasil Proses Belajar Mengajar. Bandung : PT Remaja Rosdakarya.

Sugiyono. (2010). Metode Penelitian Pendidikan Pendekatan Kuantitatif, Kualitatif dan RED. Bandung : Alfabeta. 
Suparman, Atwi. (1997). Desain Instruktional. Jakarta: Rineka Cipta.

Surwiyati. (2009). Pengaruh Pembelajaran Modul dan Kooperatif (Jigsaw), Tingkat Inteligensi Terhadap Hasil Belajar Ekonomi Siswa SMA Negeri 1 Lawang Tahun 2009-2010. Semarang : Tesis. Tidak diterbitkan

Suryaningsih, Nunik Setiyo. (2010). Pengembangan media cetak modul sebagai media pembelajaran mandiri pada mata pelajaran teknologi Informasi dan Komunikasi kelas VII semester 1 di SMPN 4 Jombang. Surabaya: Skripsi yang tidak dipublikasikan.

Susanto, Ahmad. (2013). Teori Belajar dan Pembelajaran di Sekolah Dasar. Jakarta: Kencana Prenada Media Group.

Syah, Muhibbin. (2007). Psikologi Pendidikan. Bandung : PT Remaja Rosdakarya.

Thoha, Chatib. (2003). Teknik Evaluasi Pendidikan. Jakarta: PT. Grafindo Persada.

Tirtarahardja, Umar dan La Sulo. (2009). Pengantar Pendidikan. Jakarta: Rineka Cipta.

Uno, Hamzah B. (2006). Orientasi Baru dalam Psikologi Pembelajaran. Jakarta: PT Bumi Aksara

Winkel,W.S. (2007). Psikologi Pengajaran. Yogyakarta: Media Abadi.

Yamin, Martinis dan Ansari, Bansu I. (2009). Taktik Pengembangan Kemampuan. Individual Siswa. Jakarta : Gaung Persada Press. 